\title{
Impact of globalization on the development of commerce
}

\author{
Regina Salikhova ${ }^{1, *}$, Renata Dyganova ${ }^{1}$, Ekaterina Khusainova ${ }^{1}$, and Anna Derbeneva ${ }^{1}$ \\ ${ }^{1}$ Kazan State Power Engineering University, Department of Economics and Organization of Production, 420066, Kazan, str. \\ Krasnoselskaya, 51, Russian Federation
}

\begin{abstract}
Globalization, the transition to an information society - modern processes of social development, due to a number of factors: the structure of social reproduction of countries, the level of economic development of countries, the availability of natural resources, the peculiarities of the internal market, etc. Globalization and the increasingly active use of digital technologies are affecting changes in the country's internal trade, increasing the share of electronic commerce in its composition. Electronic commerce predetermines the development of channels of distribution of goods and services different from traditional channels, and the applied business processes make it possible to discover and apply existing reserves and previously unused potential opportunities in economic activity in order to increase not only the income received, but also provide goods to remote (and small) populations. points.
\end{abstract}

\section{Introduction}

Globalization is a modern process of social development, driven by the following factors:

- the structure of the social reproduction of countries. The differentiated production structure creates conditions for more intensive development of foreign economic relations.

- the level of economic development of countries. The dynamics of growth of national income per capita determines the potential for the development of foreign economic relations.

Availability of natural resources. The implementation of the above determinants in the development of foreign economic relations is possible only with a fairly high growth in industrial production. A country with natural resources could be involved in international trade and at a low level of industrial development.

- peculiarities of the domestic market. The capacity, size of the domestic market (number of consumers, age composition, etc.), differentiation of demand determine the country's involvement in foreign trade.

- Interaction with international organizations. Mechanisms of interaction with international organizations (IMF, WTO, BRD, etc.) make it possible for the country to "exit lentrance" international markets.

The changes taking place in the system of social relations (transition to the informational type of society) also transform the system of social reproduction itself; in this regard, the idea of the nature, role of competition, the role of the monopoly, the market behavior of economic entities, that is, the changes in the conditions of the external environment, affect the processes taking place within the system of public reproduction, is changing. In this case, it is important to note the role of trade in the system of public production:

- Trade and organizes, regulates and regulates the market of consumer goods, ensuring the sale and consumption of goods, establishing in the course of sale the most obvious link between production and consumption, identifying the degree of production development;

- Trade improves the efficiency of the resources used, organizes the implementation of the results of progress, ensures the continuity of the commodity and monetary turnover;

- The links established by domestic trade with production sectors are also multidimensional. Domestic trade provides mutually advantageous exchange of goods (raw materials, materials, components) between the industries;

- the process of money circulation is ensured through trade. The speed of money circulation directly depends on the speed of circulation of goods, the higher the speed of communication of goods, the less the money supply is subject to inflationary processes, and the time of circulation and transfer of goods from manufacturers to consumers is reduced.

The aim of the study is therefore to determine the impact of globalization on trade development.

\section{Materials and methods}

\subsection{Brief Literature Review}

The development of the theory of globalization was preceded by the transformation of scientific views of the role of competition (its types) in the system of social reproduction. In the works of representatives of scientific

\footnotetext{
* Corresponding author: regina-salixova@list.ru
} 
schools, various approaches to the theory of competition have been proved. Representatives of the classical economic school criticized the policy of protectionism, believing that the economy should develop naturally (similar to the laws of nature); Freedom of choice in economic relations should be present [5]. In the view of [6] competition in the sphere of circulation is the competition of capital, as a result of which efficiency, first of all, should be achieved by reducing the expenses of circulation. The works [2, 7] substantiate the prerequisites of the category "globalization" as a vector of development of the theory of competition and monopoly. The further development of the theory of competition in the context of the development of the "first wave" of globalization was reflected in the works [9]:... "the expansion of distribution markets is possible through the emergence of new" demand "agents. Modern studies on competition $[19,20]$ justify that the development of competition involves obtaining "new knowledge," embodied in "new combinations [20]; economic entities should not... " move resources where profits are highest within existing boundaries "; and must create these competitive advantages by changing the boundaries themselves [19]. In applying research on the theory of competition to distribution (trade), it is important to note that "new combinations" and "border change" are manifested in the development of remote trade (especially in electronic), since modern trade globalization is characterized by the development of remote trade based on the use of modern technologies.

The authors [9] suggest that electronic commerce is a substitute for traditional commerce. However, according to [3], electronic commerce is part of traditional retail (Fig.1). The authors [1,11-15, 16 - 18] consider certain aspects of remote trade, its socio-economic efficiency, the implementation of business processes, model development (a large number of works are devoted to models B2C, B2B). However, the studies of modern authors practically do not reflect the interaction and mutual influence of traditional and remote trade in the context of globalization.

\subsection{Methods}

The empirical base of the study is compiled by data from Rosstat, the Federal Tax Service, and Internet sources. The work was carried out on the basis of collection and synthesis (synthesis method), systematization (system method) of materials obtained from official information resources, analysis of practical experience.

\section{Results and Discussion}

The modern model of "globalization" is characterized by the following dialectical trend - this is the "compression" of competition in the domestic market with "expansion" in the external (global) market [4]. The dialectical trend is generated by natural market processes, when economic entities seeking to have a larger market share "enlarge" activities, there is a concentration of production with the subsequent specialization of production and management functions. With this development of economic events, monopolies are formed. At the same time, economic actors in the national market tend to expand as a way of protecting against monopolies (transnational corporations), actively "exciting foreign markets." In the domestic market there is a decrease in the number of business entities as a result of their consolidation and integration. This explains the process of "compression" of competition in the domestic market. On the contrary, the opposite trend is inherent in the global market, since one of the ways of development and "growth" of economic entities is its extensive development, manifested through the "seizure" of new territories and new markets.

In such conditions, trade organizations are forced to change the traditional approach to trade and technological processes. This is due to the fact that trade organizations operate in the field of circulation and are the final element of commodity circulation. Changing the ways and factors (including the "combination of economic resources") of bringing goods to the end users, which will determine the directions of intensive development of trade organizations, will undoubtedly increase the effectiveness of their activities.

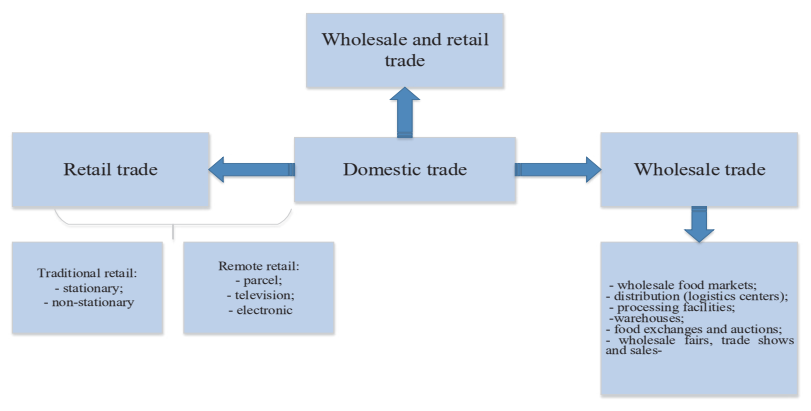

Fig. 1. Composition of domestic trade.

Modern technologies, as well as trends in social development due to the influence of globalization, allow not only to separately develop formats of traditional and electronic commerce, but also to combine them.

This is especially relevant for Russia. The large length, the presence of small and remote settlements form a "geographical gap," where the separate presence of traditional, remote (including electronic) trading enterprises will be inefficient. That is why combining forms of trade will achieve a synergistic effect: to increase the competitiveness of "combined" trade organizations, to increase the socio-economic efficiency of trade.

So, dark store ("dark shop", or shop without buyers) became one of new formats in the domestic market. This format first appeared in London in the early 2000s. in the form of a Sainsbury's network warehouse for buyers purchasing goods online, but this warehouse quickly closed in due to the lack of demand for such a trading format. Only in 2009, the British trading network Tesco repeated an attempt to introduce an innovative format.

The dark store format itself is a kind of trading room, without consumers. In the trading room there are pickers who form an online consumer order. Buyers pick up this order at the point of issue. The main idea of developing a 
new format is to reduce the time for collecting and issuing orders. There are no signs, advertisements and cash centers in the dark store.

The advantage of this format is the lack of customer service expenses. The development of this format in the regions also has a number of advantages, since the cost of maintaining this format is lower than the cost of maintaining distribution cents.

The dark store format mainly sells essential goods, including food. In Russia, the format was first tested in 2013 by M-video, but later the company abandoned the development of this format. The trend of increasing online purchases has led to the location of warehouses near industrial logistics centers. In 2017, in the dark store format, the Hyperglobus store began to sell goods, in 2018 Perekrestok and Leroy Merlin. However, this format accounts for only $0.01 \%$ of Russia trade turnover, since there are regulatory restrictions on the sale of a number of goods in this format.

The combined format, which includes elements of both traditional and electronic commerce, can also include the drive market format. The technology of selling goods is that the buyer makes purchases without leaving the car. The buyer selects the goods on the moving tray, on each of which a certain set of goods of one commodity group is represented, puts them on a transport belt. The cashier punches the goods, either passes purchases to the client, or packs them in the trunk of the car. The purchase process takes a few minutes. In the USA, the drive market format involves a preliminary online application from the consumer. The consumer receives a ready order without leaving the car. In 2017, the IKEA trading network offered consumers a new mobile application "Place," through which it is possible to visualize and evaluate the product and its location in consumer homes.

Many traditional retailers also have online stores, interacting with consumers through interactive storefronts. The trend of ROPO is increasing - the process of searching the Internet for information about the product before buying it in a stationary trading facility. According to the electronic commerce agency Absoluten, consumer $82 \%$ in the process of choosing a product through mobile devices analyze information about manufacturers of the product, its suppliers, subsequently $18 \%$ of which make purchases within 24 hours.

The combined format, which includes elements of both traditional and electronic commerce, can also include the drive market format. The technology of selling goods is that the buyer makes purchases without leaving the car. The buyer selects the goods on the moving tray, on each of which a certain set of goods of one commodity group is represented, puts them on a transport belt. The cashier punches the goods, either passes purchases to the client, or packs them in the trunk of the car. The purchase process takes a few minutes. In the USA, the drive market format involves a preliminary online application from the consumer. The consumer receives a ready order without leaving the car.
Table 1. Benefits of Combining Electronic and Traditional Trading for Sellers and Consumers.

\begin{tabular}{|c|c|c|}
\hline $\begin{array}{l}\begin{array}{l}\text { Benefits } \\
\text { consumers }\end{array} \\
\end{array}$ & $\begin{array}{l}\text { Benefits for } \\
\text { sellers }\end{array}$ & The resulting effect \\
\hline $\begin{array}{l}\text { Reducing the } \\
\text { time to receive } \\
\text { information about } \\
\text { the product }\end{array}$ & $\begin{array}{l}\text { The ability to } \\
\text { advise } \\
\text { consumers } \\
\text { around the clock }\end{array}$ & Reduced time spent \\
\hline $\begin{array}{l}\text { Round the clock } \\
\text { access to viewing } \\
\text { information about } \\
\text { the product, the } \\
\text { ability to make } \\
\text { transactions } \\
\text { around the clock } \\
\text { (purchase of } \\
\text { goods) }\end{array}$ & $\begin{array}{l}\text { The ability to } \\
\text { work around the } \\
\text { clock without } \\
\text { additional costs }\end{array}$ & $\begin{array}{l}\text { Reducing time, } \\
\text { financial costs }\end{array}$ \\
\hline $\begin{array}{l}\text { The number of } \\
\text { resellers is } \\
\text { reduced, which is } \\
\text { reflected in the } \\
\text { price of goods } \\
\text { (services, } \\
\text { information) }\end{array}$ & $\begin{array}{l}\text { Possibility of } \\
\text { establishing } \\
\text { contact with the } \\
\text { consumer } \\
\text { without the } \\
\text { participation of } \\
\text { resellers }\end{array}$ & $\begin{array}{l}\text { Reducing time, } \\
\text { financial costs }\end{array}$ \\
\hline $\begin{array}{l}\text { Possibility of } \\
\text { virtual visit to the } \\
\text { "store" (local, } \\
\text { regional, } \\
\text { international) }\end{array}$ & $\begin{array}{l}\text { Possibility of } \\
\text { selling goods to } \\
\text { domestic and } \\
\text { foreign } \\
\text { consumers. }\end{array}$ & $\begin{array}{l}\text { Increase } \\
\text { assortment, decrease } \\
\text { in time costs, increase } \\
\text { in the number of } \\
\text { consumers, decrease } \\
\text { in financial costs, } \\
\text { increase in sales } \\
\text { markets }\end{array}$ \\
\hline $\begin{array}{l}\text { The quality of } \\
\text { services before } \\
\text { and after-sales } \\
\text { service improves }\end{array}$ & $\begin{array}{l}\text { Possibility of a } \\
\text { more "flexible" } \\
\text { approach to the } \\
\text { provision of } \\
\text { services }\end{array}$ & $\begin{array}{l}\text { Reduced time costs, } \\
\text { increased sales of } \\
\text { goods }\end{array}$ \\
\hline $\begin{array}{l}\text { The possibilities } \\
\text { of obtaining } \\
\text { information about } \\
\text { the product (text, } \\
\text { graphics, video, } \\
\text { voice) are } \\
\text { expanding }\end{array}$ & $\begin{array}{l}\text { Reduced } \\
\text { personnel costs }\end{array}$ & $\begin{array}{l}\text { Reduced time costs, } \\
\text { reduced } \\
\text { costs. }\end{array}$ \\
\hline \multicolumn{2}{|c|}{$\begin{array}{l}\text { The variety of forms of payment is } \\
\text { increasing }\end{array}$} & $\begin{array}{lr}\text { Variability } & \text { of } \\
\text { settlements } & \text { with } \\
\text { consumers, suppliers }\end{array}$ \\
\hline \multicolumn{2}{|c|}{$\begin{array}{l}\text { The speed increases and the time of } \\
\text { asset circulation decreases }\end{array}$} & $\begin{array}{l}\text { Growth of economic } \\
\text { rates, reduction of } \\
\text { inflation }\end{array}$ \\
\hline \multicolumn{2}{|c|}{$\begin{array}{l}\text { Decrease in the amount of speculative } \\
\text { capital from intermediaries }\end{array}$} & $\begin{array}{l}\text { Increased investment } \\
\text { in trade infrastructure }\end{array}$ \\
\hline
\end{tabular}

\section{Conclusions}

As a result of the study, the following conclusions can be drawn. In relation to the realities of modern social conditions, we note that the intensification of competition, the "rigidity" of the nature and process of competition; modern economic actors, faced not only with rivalry within the country, but also with "external" rivalries, create (or seek to create) new combinations to increase the viability of the firm.

Thus, we note that globalization has the following impact on the development (transformation) of trade: 
deepening the specialization of trade organizations, intensive introduction of information technologies into trade. Technological improvement of the production sphere logically implies the need to transform the distribution sphere. And here, it must be borne in mind that in the field of distribution, the production process is replaced by technological, with the accompanying addition of a set of services to bring goods to end consumers. Distribution of manufactured goods is carried out through trading organizations: wholesale, retail. The modern distribution system is a complex mechanism consisting of various elements that are part of both retail and wholesale trade. It is worth noting separately the increasing role of information (especially electronic) systems in the field of distribution. Naturally, due to the so-called "information inequality" or "information gap," countries have different possibilities for using this resource, this situation is inherent in individual regions within the country. However, we note that the modern model of globalization involves, among other things, the formation of a single information space, which entails a change in the nature of competition in trade, giving it a "virtual image."

The evolution of the types of trading enterprises in Russia is much faster than in European countries, since the development of Russian trade is based on the experience of European countries. Also, competition against global trading structures contributes to such an active development of various types of trading enterprises.

The emergence of new types of trading enterprises depends on infrastructure, purchasing power, market specifics, and the demographic structure of the regions. Therefore, unfortunately, the intensive development of new types of trade enterprises concerns only economically developed regions with a fairly large population and density of residence.

Currently, there is a tendency to diversify elements of the composition of domestic trade. Despite the fact that electronic commerce is the most dynamic element of retail trade, large trade organizations successfully combine different types of sales, without completely automating all trade processes, understanding the importance and significance of traditional trade, as well as other types of remote trade (for example, parcel and television). The use of various sales channels in domestic trade creates the prerequisites for the formation of competitive advantages of trade organizations, which is especially important in the context of the development of modern globalization and the identified dialectical trend.

\section{References}

1. R.R. Dyganova, Povyshenie social'noekonomicheskoj effektivnosti distancionnoj torgovli. Kand. Diss. [Improving the socioeconomic efficiency of distance trading. Cand. Diss.], Moscow, 177 (2019)
2. V.I. Lenin, Imperialism as the Highest Stage of Capitalism, Full collection op. (5th ed., M., 315, 1962)

3. GOST R 51303-2013, Trade, Terms and definitions (approved by order of the Federal Agency for Technical Regulation and Metrology [Electronic resource], 582-st (28 August 2013) (with amendments and additions dated 29 March 2016) Available at: http://base.garant.ru (accessed: 05.09.2017)

4. V.A. Gordeev, S.V. Shkiotov, National competitiveness in the context of globalization: monograph (Publishing house: YaGTU, 174, 2009)

5. W. Petty, A. Smith, D. Ricardo, J. Keynes, M.M. Friedman, Classics of Economic Thought: Works (EKSMO-Press Publishing House, 896, 2000) (Series "Anthology of Thought")

6. K. Marx, F. Engels, To the criticism of political economy (2nd ed., M.: Publishing house of political literature, 770, 1959)

7 Y.Yu. Deputatova, Y.I. Pshenitsyna, S.B. Ilyashenko, V.A. Baskakov, A.O. Zvereva, Consumer behavior in the context of global economic transformations, European Research Studies Journal 21(2), 95-109 (2018)

8. A. Marshall, Principles of Economic Science (M., 172, 1993)

9. E.V. Pilipenko, E.V. Garbuk, Transformaciya principov predprinimatel'skoj deyatel'nosti V usloviyah krizisa na primere torgovyh center [Transformation of the principles of entrepreneurial activity in a crisis on the example of shopping centers], Internet-zhurnal Naukovedenie [Internet journal of Science of Science], 1, 30 (2015)

10. R.R. Salihova, R.R. Dyganova, Osobennosti predostavleniya uslug $\mathrm{v}$ distancionnoj torgovle $\mathrm{V}$ Rossii [Features of the provision of services in distance trading in Russia], Finansovaya ekonomika [Financial Economics], 3, 194-198 (2019)

11. G. Thain, J. Bradley, Trade Wars: The Battle for Success on the Counter and Online (M.: ALPINA PABLISHER, 315, 2013) (in Russian)

12. Jan Thieme, Distance selling [trans. with him. L. Bolkhovitina] (M.: Vershina, 376, 2006)

13. E.V. Timoshkina, Directions of development of electronic commerce in the Russian Federation [Electronic resource], Bulletin of the Izhevsk State Agricultural Academy, 4 (33), 37-39 (2012) Available at: http://elibrary.ru (accessed: 19.11.2017)

14. A.S. Tretyakova, M.A. Petrusha, Electronic trade as a special channel for the distribution of goods [Electronic resource], Economy and society, 4-2 (23), 359-361 (2016) Available at: http://elibrary.ru (accessed: 05.02.2018)

15. Yu.R. Tutaeva, Information-network dominant of the development of the market mechanism in modern conditions: diss. ... Cand. econom. Sciences: 08.00.05, M., 184 (2014) 
16. S. Ilyashenko, M. Belyakova, A. Zvereva, Possibilities of application of digital tools by the organizations of sphere of services and trade in the Russian Federation, IOP Conference Series: Materials Science and Engineering 940(1),012059 (2020)

17. L.V. Larchenko, , R.A. Kolesnikov, L. Mukhametova, Russian oil and gas industry as a sphere of international interests and economic cooperation, E3S Web of Conferences 161,01006 (2020)

18. E.A. Tyurina, M. Chinhai, Ts. Cao, Electronic commerce in Russia and China: analysis of institutions and development trends [Electronic resource], Management and business administration, 4, 56-77 (2013) Available at: http://elibrary.ru (accessed: 05.09.2017)

19. M. Porter, International Competition: Translated from English, Ed. and with a foreword by V.D. Shchetinin (M.: Mezhdunar.otnosheniya, 25, 1993)

20. J. Schumpeter, Theory of economic development (M.: Progress, 1982) 